\title{
Partial Nitrification of Ammonium-Rich Wastewater as Pretreatment for Anaerobic Ammonium Oxidation (Anammox) Using Membrane Aeration Bioreactor
}

\author{
Yu-Jou Feng, ${ }^{1 *}$ Szu-Kung Tseng, ${ }^{1}$ Tsung-Hui Hsia, ${ }^{2}$ Chun-Ming Ho, ${ }^{2}$ and Wen-Po Chou ${ }^{1}$ \\ Graduate Institute of Environmental Engineering, National Taiwan University, 71 Chou-Shan Rd., Taipei, Taiwan, \\ R.O.C. ${ }^{1}$ and Department of Safety Health and Environmental Engineering, Tung Nan Institute of Technology, \\ No. 152, Sec. 3, Pei-Shen Rd., Shen-Kun Village, Taipei, Taiwan, R.O.C. ${ }^{2}$
}

Received 1 November 2006/Accepted 29 May 2007

\begin{abstract}
A lab-scale membrane aeration bioreactor (MBR) system was developed for treating synthetic ammonium-rich wastewater to yield an appropriate $\mathrm{NO}_{2}^{-} / \mathrm{NH}_{4}^{+}$mixture as a pretreatment for anaerobic ammonium oxidation (Anammox). The effluent with a suitable $\mathrm{NO}_{2}-/ \mathrm{NH}_{4}{ }^{+}$ratio $(1: 1$ to $1: 1.3)$ was obtained in $24 \mathrm{~h}$ using the developed MBR system under suitable conditions. Additionally, the control of bulk dissolved oxygen (DO) level under a desired condition (anoxic condition) was easier and more economical than traditional aeration systems. An optimal initial alkalinity of $1500 \mathrm{mg} \mathrm{CaCO} l t^{-1}$ was necessary for achieving $50 \%$ partial nitrification of wastewater with an initial ammonium concentration of $510 \mathrm{mg} \mathrm{NH}-\mathrm{N} t^{-1}$ within $24 \mathrm{~h}$. Furthermore, there is no need for $\mathrm{pH}$ adjustment by adding a base or an acid throughout the reaction if the initial alkalinity is appropriately controlled. Both the appropriate $\mathrm{NO}_{2}-/ \mathrm{NH}_{4}{ }^{+}$ratio and the low DO level make this MBR system an ideal system for Anammox.
\end{abstract}

[Key words: partial nitrification, ammonia-oxidizing bacteria, Anammox, membrane aeration bioreactor]

The operational costs of the conventional nitrificationdenitrification nitrogen removal process are to a great extent related to the oxygen and organic matter requirements. Some new processes have been developed recently to reduce these costs. One of these is a rapid method of biological nitrogen removal. The combination of the preceding partial nitrification and the subsequent anaerobic ammonium oxidation (Anammox) is regarded as a promising new method of removing nitrogen from wastewater with a low $\mathrm{C} / \mathrm{N}$ ratio and a large quantity of ammonium $(1,2)$.

Complete nitrification is carried out in two steps: ammonia is first converted to nitrite by ammonia-oxidizing bacteria (AOB), and then the nitrite is further converted to nitrate by nitrite-oxidizing bacteria (NOB). AOB use 1.5 moles and NOB 0.5 mole of oxygen per mol of ammonia (Eqs. 1 and 2); thus, complete nitrification requires 2 moles of oxygen (Eq. 3), whereas $50 \%$ partial nitrification requires 0.75 mole of oxygen per mol of nitrogen (Eq. 4), implying a $62.5 \%$ less oxygen demand for $50 \%$ partial nitrification compared with complete nitrification (3).

$$
\begin{aligned}
& \mathrm{NH}_{4}^{+}+1.5 \mathrm{O}_{2} \rightarrow \mathrm{NO}_{2}^{-}+\mathrm{H}_{2} \mathrm{O}+2 \mathrm{H}^{+} \\
& \text {(nitritation, by AOB) } \\
& \mathrm{NO}_{2}^{-}+0.5 \mathrm{O}_{2} \rightarrow \mathrm{NO}_{3}^{-} \quad \text { (nitratation, by NOB) } \\
& \mathrm{NH}_{4}^{+}+2 \mathrm{O}_{2} \rightarrow \mathrm{NO}_{3}^{-}+\mathrm{H}_{2} \mathrm{O}+2 \mathrm{H}^{+} \\
& \text {(complete nitrification) }
\end{aligned}
$$

\footnotetext{
* Corresponding author. e-mail: jffeng.hsia@msa.hinet.net
} phone: $+886-2-29361176$ fax: $+886-2-86614173$

$$
\begin{aligned}
& \mathrm{NH}_{4}^{+}+0.75 \mathrm{O}_{2} \rightarrow 0.5 \mathrm{NH}_{4}^{+}+0.5 \mathrm{NO}_{2}^{-}+0.5 \mathrm{H}_{2} \mathrm{O}+\mathrm{H}^{+} \\
& \text {(50\% partial nitrification) }
\end{aligned}
$$

Anammox is the denitrification of nitrite with ammonium as the electron donor to yield nitrogen gas. A preceding partial nitrification step must be performed to convert only onehalf of the ammonium to nitrite (4). The main product of the Anammox is $\mathrm{N}_{2}$; however, approximately $10 \%$ of the fed nitrogen (ammonium and nitrite) is converted to nitrate. The stoichiometry of the Anammox reaction based on mass balance over Anammox enrichment cultures (5) is given by Eq. 5 as below.

$$
\begin{aligned}
\mathrm{NH}_{4}^{+} & +1.32 \mathrm{NO}_{2}^{-}+0.066 \mathrm{HCO}_{3}^{-}+0.13 \mathrm{H}^{+} \\
\rightarrow & 1.02 \mathrm{~N}_{2}+0.26 \mathrm{NO}_{3}^{-}+0.066 \mathrm{CH}_{2} \mathrm{O}_{0.5} \mathrm{~N}_{0.15} \\
& +2.03 \mathrm{H}_{2} \mathrm{O}
\end{aligned}
$$

The combination of partial nitrification and Anammox is based on the fact that nitrite is an intermediary compound in both. Therefore, it will be convenient and economical to achieve $50 \%$ partial nitrification up to a condition wherein one-half of ammonia is converted to nitrite and the other half is not, followed by the Anammox to ensure total nitrogen removal throughout an autotrophic process. The $62.5 \%$ less oxygen demand and the absence of organic carbon addition offer considerable cost savings when compared with the conventional nitrification-denitrification system.

Nitrogen removal from wastewater using a membrane aeration bioreactor is a commonly adopted technology. Biofilm systems have several advantages, such as a very large 
surface area for biofilm attachment, the protection of microorganisms in the biofilm against unfavorable surroundings and the achievement of very high sludge age, which is of utmost importance for nitrifying bacteria $(6,7)$. Synthetic gas-permeable membranes have been extensively adopted in bioreactor aeration systems because of their higher oxygen transfer efficiency than that of traditional aeration systems (7-9).

Further oxidation of nitrite to nitrate must be prevented by controlling operation variables such as temperature, $\mathrm{pH}$, hydraulic retention time, substrate concentration and the DO level, to ensure stable partial nitrification. The activity of NOB must be reduced without affecting AOB by establishing conditions that favor AOB development. Operations can be performed at a relatively higher temperature (above $35^{\circ} \mathrm{C}$ ) and a higher $\mathrm{pH}$ (above 7) to enable AOB to predominate over NOB (4). Operation at a low DO level in the range of 0.7 to $1.4 \mathrm{mg}^{-1}$ can also more effectively suppress the activity of $\operatorname{NOB}(2,3)$. Of the operational variables described above, the control of the DO level may be the most important and is therefore a key factor for achieving partial nitrification. Both the aeration systems and the aeration patterns may importantly affect partial nitrification. In traditional aeration systems, some problems exist in controlling the DO level under a desired condition.

In this investigation, we develop a membrane aeration bioreactor for partial nitrification, in which the aeration system uses a gas-permeable silicone membrane tube. Figure 1 shows the schematic representation of concentration profiles (oxygen, ammonia, and nitrite) in the reactor. Air was made to flow into the lumen side of the membrane tube to aerate the nitrifying biofilm. Ammonium diffused slowly from the bulk solution toward the membrane. However, oxygen diffused in the opposite direction. These opposing diffusion directions of substrate yield a large active volume in the biofilm (9). In this study, we discuss the feasibility of partial nitrification on the lab-scale: about $50 \%$ ammonium was oxidized to nitrite, whereas the other half remained in

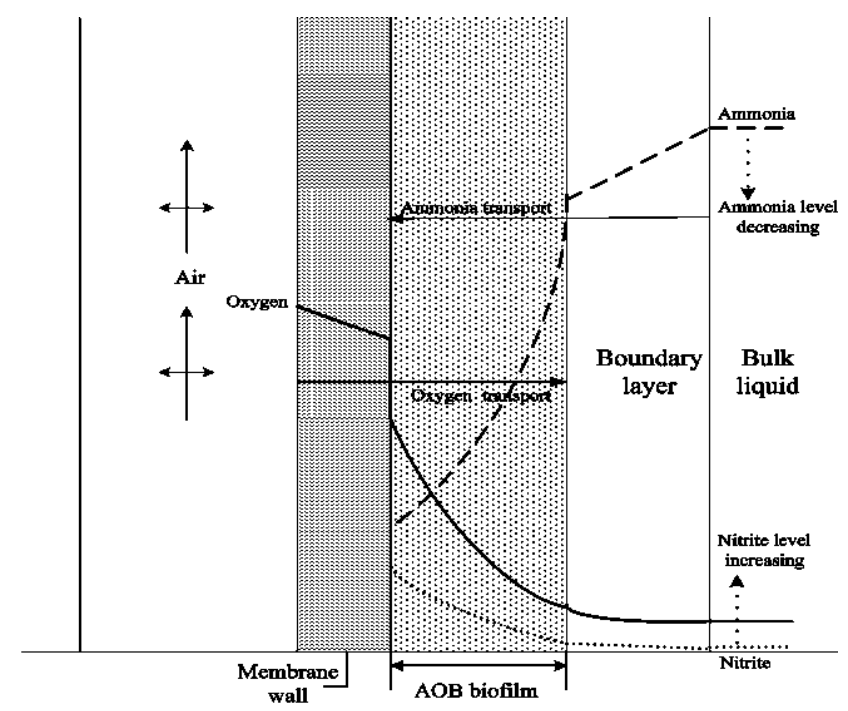

FIG. 1. Schematic representation of concentration profile (oxygen, ammonia, and nitrite) in membrane aeration bioreactor. the bioreactor. The effects of membrane aeration, initial ammonium concentration, and initial alkalinity on partial nitrification were all investigated in this study.

\section{MATERIALS AND METHODS}

Synthetic wastewater The synthetic wastewater used in this study contained $\left(\mathrm{NH}_{4}\right)_{2} \mathrm{SO}_{4}\left(1.18-2.36 \mathrm{~g} l^{-1}\right), \mathrm{NaHCO}_{3}(1.26-5.04$ $\left.\mathrm{g}^{-1}\right), \mathrm{Na}_{2} \mathrm{HPO}_{4}\left(0.09 \mathrm{~g}^{-1}\right), \mathrm{KH}_{2} \mathrm{PO}_{4}\left(0.15 \mathrm{~g} l^{-1}\right), \mathrm{MgSO}_{4} \cdot 7 \mathrm{H}_{2} \mathrm{O}(0.2$ $\left.\mathrm{g} l^{-1}\right)$ and a solution $\left(1 \mathrm{ml} l^{-1}\right)$ of trace elements $\mathrm{ZnSO}_{4} \cdot 7 \mathrm{H}_{2} \mathrm{O}(2.2$ $\left.\mathrm{g} l^{-1}\right), \mathrm{CaCl}_{2} \cdot 2 \mathrm{H}_{2} \mathrm{O}\left(7.3 \mathrm{~g} \mathrm{l}^{-1}\right), \mathrm{MnCl}_{2} \cdot 4 \mathrm{H}_{2} \mathrm{O}\left(2.5 \mathrm{~g}^{-1}\right), \mathrm{CoCl}_{2} \cdot 6 \mathrm{H}_{2} \mathrm{O}$ $\left(0.5 \mathrm{~g}^{-1}\right),\left(\mathrm{NH}_{4}\right)_{6} \mathrm{Mo}_{7} \mathrm{O}_{24} \cdot 4 \mathrm{H}_{2} \mathrm{O}\left(0.5 \mathrm{~g}^{-1}\right), \mathrm{FeSO}_{4} \cdot 7 \mathrm{H}_{2} \mathrm{O}\left(5.0 \mathrm{~g}^{-1}\right)$ and $\mathrm{CuSO}_{4} \cdot 5 \mathrm{H}_{2} \mathrm{O}\left(0.2 \mathrm{~g}^{-1}\right)$. No organic substrate was added to favor the growth of autotrophic AOB.

Cultivation of nitrifying biofilm The bioreactor was inoculated with activated sludge from a municipal wastewater treatment plant. At the beginning of this study, nitrifying bacteria were directly cultivated on a gas-permeable membrane. The formation of a nitrifying biofilm is essential to the partial nitrification of wastewater in a short time. The preceding two-stage cultivation of a nitrifying biofilm is very important for the following batch experiments. During the first 9-d batch cultivation period, the reactor was filled with synthetic wastewater at $35^{\circ} \mathrm{C}$ with a $\mathrm{pH}$ of approximately 8 and ammonium concentration was gradually increased from 100 to $500 \mathrm{mg} \mathrm{NH}_{4}-\mathrm{N}^{-1}$. During the following continuous cultivation period, synthetic wastewater that contained $500 \mathrm{mg} \mathrm{NH}_{4}-\mathrm{N}^{-1}$ was pumped continuously into the reactor at a flow rate of $3 \mathrm{ml}$ $\min ^{-1}$ for two weeks. Meanwhile, samples were withdrawn from the bulk liquid in the reactor and analyzed to confirm the nitrifying activity of the biofilm, after which the batch experiments were started.

Setup of membrane aeration bioreactor Figure 2 shows the images of the membrane aeration bioreactor developed in this study. This bioreactor, constructed from Perspex, had a working volume of $1 l$, in which a silicone membrane tube $(1.5 \mathrm{~mm}$ inner and $2.5 \mathrm{~mm}$ outer diameter by $6 \mathrm{~m}$ long; Fuji System, Tokyo) was immersed and wound around the pillars. The air was made to diffuse continuously to the lumen side of the membrane tube and the end of the tube was maintained open. Meanwhile, the contents of the reactor were completely mixed using a magnetic stirrer and maintained at $35^{\circ} \mathrm{C}$.

Batch experiments on partial nitrification Following the biofilm cultivation period, seven runs of the batch experiment were performed to assess the partial nitrification behavior, membrane aeration effect, initial ammonium concentration effect, and initial alkalinity effect of the system. In addition, a molecular biotechnology method was applied to confirm that ammonia oxidizers
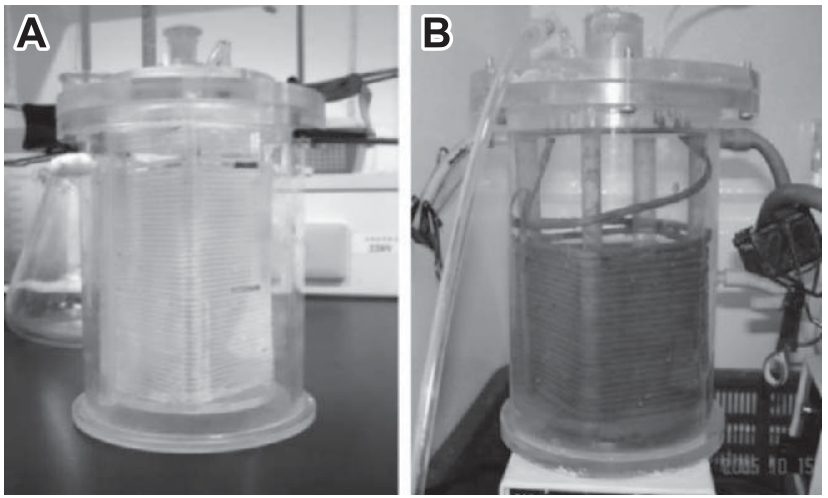

FIG. 2. Images of membrane aeration bioreactor (A) before and (B) after acclimation. 
TABLE 1. Initial conditions for batch experiments

\begin{tabular}{lccc}
\hline $\begin{array}{l}\text { Experiment } \\
\text { for assessment } \\
\text { of influence }\end{array}$ & $\begin{array}{c}\text { Mean initial } \\
\text { concentration } \\
\left(\mathrm{mg} \mathrm{NH}_{4}^{+}-\mathrm{N}^{-1}\right)\end{array}$ & $\begin{array}{c}\text { Mean initial } \\
\text { alkalinity } \\
\left(\mathrm{mg} \mathrm{CaCO}_{3} l^{-1}\right)\end{array}$ & $\begin{array}{c}\text { Air supplied } \\
\text { to lumen of } \\
\text { silicon tube }\end{array}$ \\
\hline $\begin{array}{l}\text { Air } \\
\text { A }\end{array}$ & 500 & 1500 & Yes \\
B & 500 & 1500 & No \\
$\begin{array}{l}\text { Initial ammonium } \\
\text { concentration }\end{array}$ & & & \\
C & 510 & 1500 & Yes \\
D & 250 & 1500 & Yes \\
Initial alkalinity & & & \\
E & 510 & 750 & Yes \\
F & 510 & 1500 & Yes \\
G & 510 & 3000 & Yes \\
\hline
\end{tabular}

a Assessments of the influence of air (A, B), initial ammonium concentration $(\mathrm{C}, \mathrm{D})$, and initial alkalinity $(\mathrm{E}-\mathrm{G})$ on partial nitrification.

predominated the biofilm. In one experiment (the blank test), the flow of air into the membrane tube was stopped to confirm that air was utilized by the biofilm during the progress of other batch experiments, which were performed under different initial concentrations (510 and $250 \mathrm{mg} \mathrm{NH}_{4}-\mathrm{N}^{-1}$ ) and different initial alkalinities $\left(750,1500\right.$, and $\left.3000 \mathrm{mg} \mathrm{CaCO}_{3} l^{-1}\right)$. Table 1 shows the summary of the initial conditions of these batch experiments. All batch experiments were carried out at $35^{\circ} \mathrm{C}$, and the initial $\mathrm{pH}$ was approximated 8 without adjustment by the addition of an acid or a base throughout the reaction.

Analytical methods Bulk pH and DO levels were monitored. Samples were withdrawn from the reactor and analyzed to determine the levels of ammonium, nitrite, nitrate and alkalinity. The concentrations of ammonium, nitrite and nitrate were all measured by ion chromatography (DX-120; Dionex Corporation, Sunnyvale, CA, USA). Alkalinity was determined by titration method in accordance with standard methods. Dissolved oxygen (DO) concentration was measured using a DO meter (YSI-550A; YSI Incorporated, Yellow Springs, $\mathrm{OH}, \mathrm{USA}$ ), and the $\mathrm{pH}$ was measured using a $\mathrm{pH}$ meter (MP 220; Mettler-Toledo GmbH, Laboratory \& Weighing Technologies, Greifensee, Switzertland).

\section{RESULTS}

\section{Formation of nitrifying biofilm on membrane tube}

The formation of a nitrifying biofilm on the membrane tube was necessary and accomplished before the batch experiments. During the first 9-d batch cultivation period, the inoculated activated sludge was gradually acclimated and finally a thin layer of brownish biofilm was observed on the outer surface of the membrane tube. During the following continuous cultivation period, the biofilm became thicker and darker, and much more firmly attached to the tube's surface. The batch experiments were started after the nitrifying activity of the biofilm was confirmed by analyzing the samples withdrawn from the bulk liquid (data not shown). Figure 2 shows the images of this membrane bioreactor before and after biofilm acclimation.

\section{Confirmation of use of air by nitrifying biofilm}

One batch experiment was conducted in which air was not supplied into the lumen side of the membrane tube to confirm that air was utilized by the biofilm during the progress of other batch experiments. The result of this blank test, as shown in Fig. 3, indicated that the $\mathrm{pH}$ or the nitrogenous compound concentrations almost always remained at the

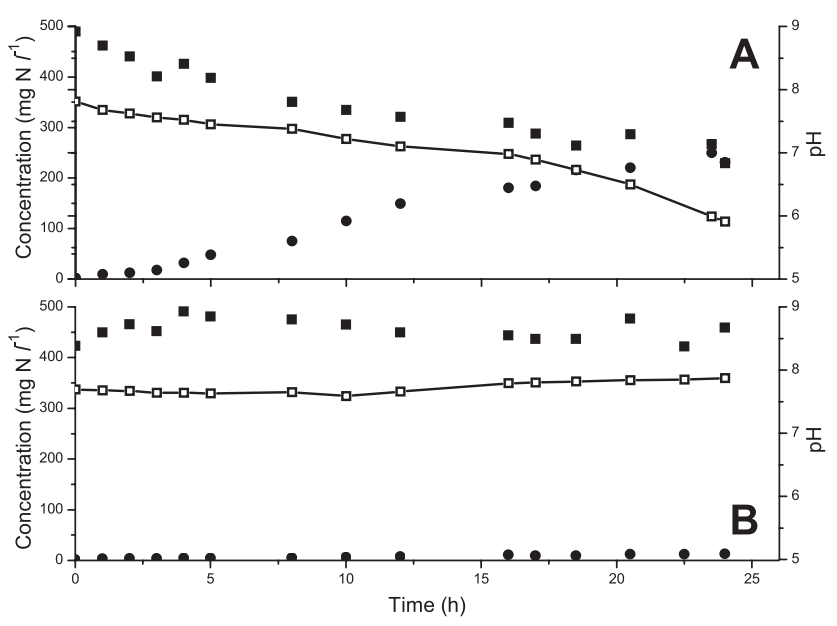

FIG. 3. Time-dependent changes in $\mathrm{pH}$ and concentrations during batch tests for confirmation of use of air in partial nitrification. (A) With air supply and (B) without air supply (initial $\mathrm{pH}, 8$; temperature, $35^{\circ} \mathrm{C}$ ). Symbols: closed squares, $\mathrm{NH}_{4}^{+}-\mathrm{N}$; closed circles, $\mathrm{NO}_{2}^{-}-\mathrm{N}$; and open squares, $\mathrm{pH}$.

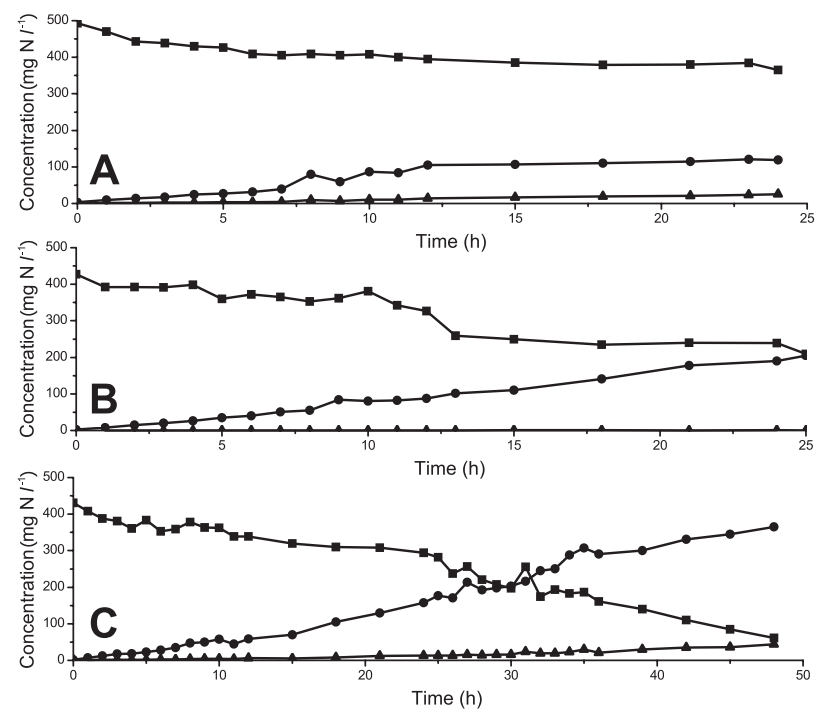

FIG. 4. Time courses of bulk concentrations during batch tests with mean initial concentration of $510 \mathrm{mg} \mathrm{NH}_{4}^{+}-\mathrm{N} l^{-1}$ (initial $\mathrm{pH}, 8$; temperature, $35^{\circ} \mathrm{C}$ ) under different initial alkalinities: (A) $750 \mathrm{mg} \mathrm{CaCO}_{3} l^{-1}$ (insufficient), (B) $1500 \mathrm{mg} \mathrm{CaCO} l^{-1}$ (normal), and (C) $3000 \mathrm{mg} \mathrm{CaCO}_{3} l^{-1}$ (excess). Symbols: squares, $\mathrm{NH}_{4}{ }^{+} \mathrm{N}$; circles, $\mathrm{NO}_{2}^{-}-\mathrm{N}$; and triangles, $\mathrm{NO}_{3}^{-}-\mathrm{N}$.

initial state during the 24-h batch test. However, when air was supplied continuously to the membrane tube, ammonium concentration decreased as the $\mathrm{pH}$ level decreased from 8.1 to below 6 at the end of the batch test. These results confirmed that the membrane tube was gas-permeable and responsible for the aeration of the biofilm; supplying air into the membrane tube resulted in the oxidation of ammonium to nitrite.

\section{Effects of initial alkalinity on partial nitrification}

The initial alkalinity effect on partial nitrification was investigated in this study, also conducted at $35^{\circ} \mathrm{C}$ with an initial $\mathrm{pH}$ of approximately 8 . Figure 4 shows the time-dependent variations in nitrogenous compound concentrations under 

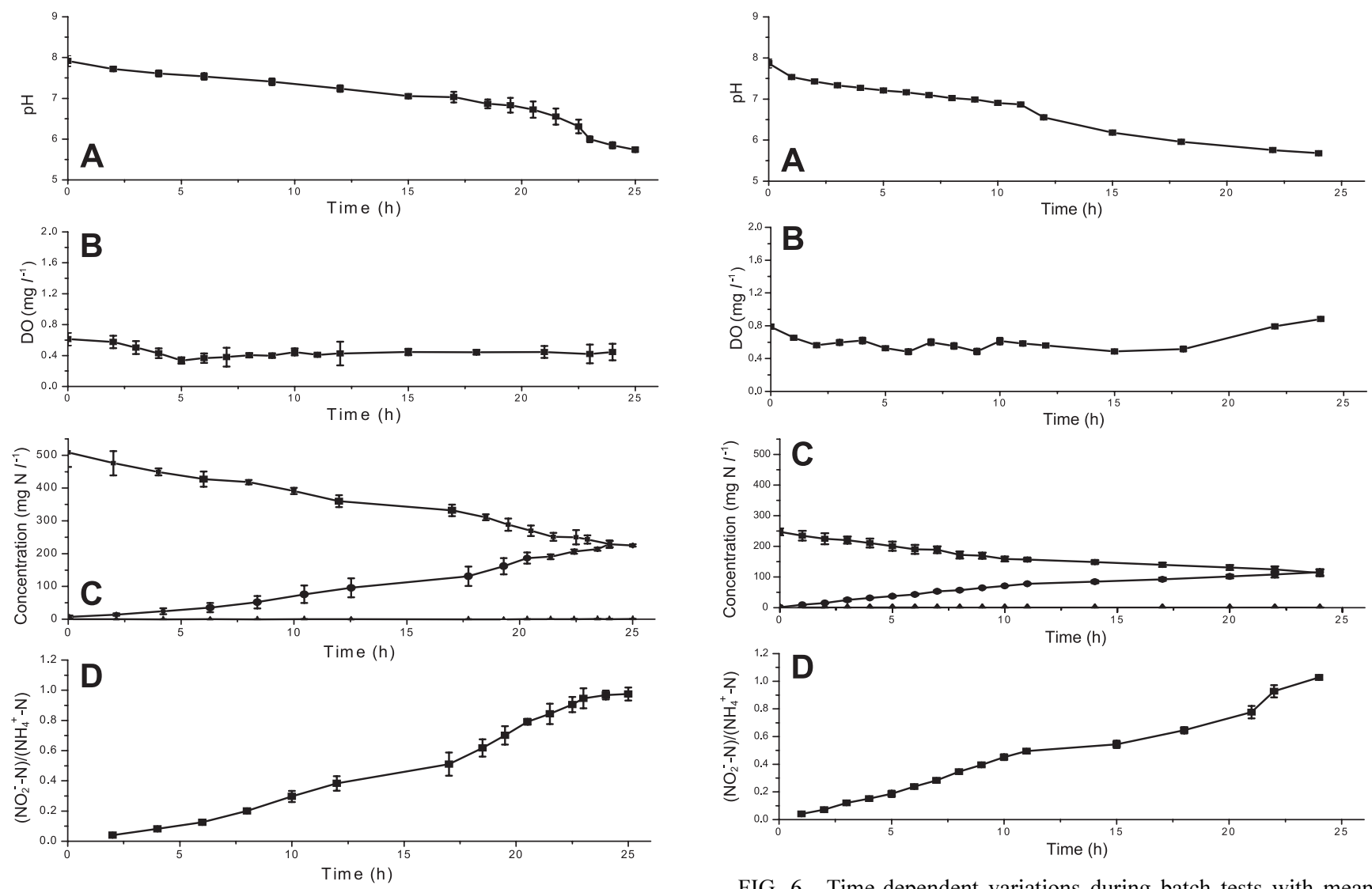

FIG. 5. Time-dependent variations during batch tests with mean initial concentration of $510 \mathrm{mg} \mathrm{NH}{ }^{+}-\mathrm{N}^{-1}$ (initial $\mathrm{pH}, 8$; temperature, $35^{\circ} \mathrm{C}$ ). (A) $\mathrm{pH}$, (B) DO level, (C) $\mathrm{NH}_{4}{ }^{+}-\mathrm{N}, \mathrm{NO}_{2}^{-}-\mathrm{N}, \mathrm{NO}_{3}{ }^{-}-\mathrm{N}$ concentrations, and (D) $\mathrm{NO}_{2}^{-}-\mathrm{N} / \mathrm{NH}_{4}^{+}-\mathrm{N}$ ratio. Bars indicate one standard deviation of three sets of data. Symbols in panel C: squares, $\mathrm{NH}_{4}{ }^{+} \mathrm{N}$; circles, $\mathrm{NO}_{2}^{-}-\mathrm{N}$; and triangles, $\mathrm{NO}_{3}^{-}-\mathrm{N}$.

different initial alkalinities. It is clear that there was a high correlation between ammonia oxidation and the initial alkalinity. Figure 4A shows that ammonia oxidation almost stopped for $12 \mathrm{~h}$ because of the lack of sufficient alkalinity to neutralize the released $\mathrm{H}^{+}$from the nitrification reaction; then, the $\mathrm{pH}$ decreased and therefore the AOB activity was inhibited. Consequently, the conversion ratio of ammonia or nitrite was far less than $50 \%$. Figure $4 \mathrm{C}$ shows that ammonia oxidation proceeded continuously even to the end of the 48-h batch test, because the high alkalinity contributed to the maintenance of a suitable $\mathrm{pH}$ for AOB. Consequently, ammonia was almost completely converted to nitrite. The optimal initial alkalinity was determined to be $1500 \mathrm{mg}$ $\mathrm{CaCO}_{3} l^{-1}$ from Fig. 4B, indicating that appropriate initial alkalinity was essential for achieving $50 \%$ partial nitrification in this bioreactor.

Variations in pH, DO level, nitrogenous compound concentrations and $\mathrm{NO}_{2}^{-} / \mathrm{NH}_{4}^{+}$ratio A series of batch experiments were performed to evaluate the capacity of this bioreactor to achieve $50 \%$ partial nitrification under suitable conditions. Figures 5 and 6 show the behavior of the system with mean initial concentrations of 510 and $250 \mathrm{mg} \mathrm{NH}_{4}$ $\mathrm{N} l^{-1}$, respectively. These results show that the variations in nitrogenous compound concentrations are very similar at

FIG. 6. Time-dependent variations during batch tests with mean initial concentration of $250 \mathrm{mg} \mathrm{NH}_{4}^{+}-\mathrm{N} l^{-1}$ (initial $\mathrm{pH}$, 8; temperature, $35^{\circ} \mathrm{C}$ ). (A) $\mathrm{pH}$, (B) DO level, (C) $\mathrm{NH}_{4}^{+}-\mathrm{N}, \mathrm{NO}_{2}^{-}-\mathrm{N}, \mathrm{NO}_{3}^{-}-\mathrm{N}$ concentrations, and (D) $\mathrm{NO}_{2}^{-}-\mathrm{N} / \mathrm{NH}_{4}^{+}-\mathrm{N}$ ratio. Bars indicate one standard deviation of three sets of data. Symbols in panel C: squares, $\mathrm{NH}_{4}^{+}-\mathrm{N}$; circles, $\mathrm{NO}_{2}^{-}-\mathrm{N}$; and triangles, $\mathrm{NO}_{3}^{-}{ }^{-} \mathrm{N}$.

different initial ammonium concentrations.

Figures $5 \mathrm{~A}$ and $6 \mathrm{~A}$ show that the $\mathrm{pH}$ slowly decreased with a decrease in ammonium concentration because of nitrification, in which the reacting ammonium served as an electron donor and was oxidized to nitrite with the release of $\mathrm{H}^{+}(4)$. In this study, air was sufficient to meet the oxygen demand for partial nitrification; most of the dissolved oxygen that penetrated the membrane was consumed by the biofilm and only a small amount was released to the bulk phase, leading to an anoxic condition associated with a DO level below $0.6 \mathrm{mg} l^{-1}$. Compared with Fig. $5 \mathrm{~B}$, the variation in the DO level at a lower initial concentration of $250 \mathrm{mg}$ $\mathrm{NH}_{4}-\mathrm{N} l^{-1}$ as shown in Fig. 6B appeared to be very similar to what was described above; such a low DO level in an aerobic nitrification reactor is very interesting.

Figures $5 \mathrm{C}$ and $6 \mathrm{C}$ show the variation curves of the nitrogenous compounds with different initial concentrations, indicating that the ammonium concentration decreased by about $50 \%$ and that a very small amount of nitrate was formed utill the end of batch test. In other words, the small amount of ammonium was almost completely oxidized to nitrite under this condition. Both ammonium and nitrite concentrations varied rapidly at the beginning and then gradually at the end. The initial conditions enabled AOB to predominate over NOB, such as a higher ammonium concen- 
tration, a low DO level and an elevated $\mathrm{pH}$ above $7(4,10)$; however, the activity of AOB was gradually inhibited near the end of batch test when the ammonium concentration and pH decreased markedly. Furthermore, from the bacterial community analysis results of the biofilm (data not shown), AOB were confirmed to predominate the biofilm.

The $\mathrm{NO}_{2}{ }^{-} / \mathrm{NH}_{4}{ }^{+}$ratio in the effluent in the partial nitrification is strongly correlated with the $\mathrm{pH}$ in the reactor (11). Figure 5D shows the variations in the $\mathrm{NO}_{2}^{-} / \mathrm{NH}_{4}{ }^{+}$ratio at an initial concentration of $510 \mathrm{mg} \mathrm{NH}_{4}-\mathrm{N} l^{-1}$, indicating that the $\mathrm{NO}_{2}{ }^{-} / \mathrm{NH}_{4}^{+}$ratio increased rapidly with a gradual decrease in the $\mathrm{pH}$ during the first $12 \mathrm{~h}$, whereas the ratio varied gradually with a rapid decrease in the $\mathrm{pH}$ during the following $12 \mathrm{~h}$. Compared with Fig. 5D, the variation in the ratio at an initial concentration of $250 \mathrm{mg} \mathrm{NH}_{4}-\mathrm{N} l^{-1}$, as shown in Fig. 6D, was very similar, implying that this bioreactor is quite stable and appropriate for $50 \%$ partial nitrification. These data revealed that a high ammonium concentration, an appropriate $\mathrm{pH}$ and a low bulk DO concentration in the early stage of nitrification promoted the oxidation of ammonium; however, when the ammonium concentration decreased, the drop in the $\mathrm{pH}$ and the accumulating nitrite inhibited the activity of AOB (4). Therefore, the $\mathrm{NO}_{2}^{-} / \mathrm{NH}_{4}^{+}$ ratio increased gradually and remained stable during the following $12 \mathrm{~h}$.

Ammonium surface loading (ASL) Ammonium surface loading (ASL) is defined as the amount of ammonium spread over a square meter of the surface of the silicone membrane tube, calculated to be 10.83 and $5.27 \mathrm{~g} \mathrm{NH}_{4}-\mathrm{N} \mathrm{m}^{-2}$ for the initial concentrations of 510 and $250 \mathrm{mg} \mathrm{NH}_{4}-\mathrm{N} l^{-1}$, respectively. The surface area of the tube is proportional to its length, so that a longer tube provides a larger surface area for biofilm attachment, and therefore the time needed to achieve $50 \%$ partial nitrification is shortened with an increase in tube length. In other words, $50 \%$ partial nitrification within a certain period of time may be easily achieved by the adjustment of tube length consistent with the initial ammonium concentration if the ASL only ranged from 10.83 to $5.27 \mathrm{~g} \mathrm{NH}_{4}-\mathrm{N} \mathrm{m}^{-2}$.

\section{DISCUSSION}

This approach demonstrated that the developed membrane aeration bioreactor is an efficient and economical system for achieving $50 \%$ partial nitrification, in which about $50 \%$ ammonium was oxidized to nitrite, whereas the other half remained in the reactor. The membrane tube in this bioreactor provided a high specific surface area for oxygen transfer and biofilm attachment. The air overcame the resistance of the membrane wall and uniformly passed through the membrane by diffusion. The nitrifying biofilm attached firmly to the surface of the membrane after a very short period of two-stage acclimation: a former batchwise stage and a latter continuous cultivation stage. The formation of a nitrifying biofilm on the membrane was very important for the following batch experiments. A satisfactory nitrifying biofilm on the membrane was characterized by a thick-anddark appearance, a firm adhesion to the membrane's surface, an AOB-predominant bacterial community, and a confirmed nitrifying activity. As was described above, the for- mation of a strong nitrifying biofilm is essential to achieve a stable $50 \%$ partial nitrification during a short period of time.

Regarding the utilization of air by the nitrifying biofilm, a blank test was conducted to confirm the importance of air in the reaction. Sufficient DO is necessary for nitrifying bacteria to oxidize ammonium to nitrite and further to nitrate; in other words, even the oxidation of ammonium to nitrite is impossible in the absence of air. The result of the blank test confirmed that the membrane tube was gas-permeable and responsible for the aeration of the biofilm.

Regarding the control of the bulk DO level, this MBR system achieved surprising cost savings in aeration as compared with traditional aeration systems, merely using a simple and cheap air diffuser. DO concentration affects the metabolic activity of nitrifying bacteria (10), including AOB and NOB. The bulk DO level close to that under the anoxic condition was essential for achieving stable partial nitrification. From the results of this study, the nitrifying biofilm was capable of utilizing air efficiently; the low bulk DO level was not sufficient for achieving complete nitrification. This anoxic condition in the biofilm strongly inhibited nitrite oxidation and AOB predominated NOB in the competition for oxygen because nitrite oxidizers have less affinity for oxygen than ammonium oxidizers $(4,12)$. Therefore, almost half of the ammonium was oxidized to nitrite but trace amounts of nitrate were produced. In addition, the bacterial community analysis results showed that AOB predominated the biofilm. This is a definite and strong evidence to explain why the bioreactor performed partial nitrification.

This system can achieve approximately $50 \%$ partial nitrification under suitable conditions (low DO level, elevated temperature and $\mathrm{pH}$, appropriate initial alkalinity) within $24 \mathrm{~h}$. The ammonium concentration decreased as the $\mathrm{pH}$ decreased and the concentration of nitrite increased. Ammonium oxidation was highly correlated with nitrite accumulation; almost all of the oxidized ammonium was converted to nitrite but not to nitrate. The production of an appropriate $\mathrm{NO}_{2}{ }^{-} / \mathrm{NH}_{4}{ }^{+}$mixture is critical to the Anammox to ensure total nitrogen removal throughout an autotrophic process (13). The nitrite that accumulated in this bioreactor was not further converted to nitrate. Meanwhile, the $\mathrm{NO}_{2}^{-} / \mathrm{NH}_{4}^{+}$ ratio increased gradually and remained between $1: 1$ and $1: 1.3$ untill the end of the 24 -h batch tests.

An appropriate initial alkalinity was also an important factor to achieve stable partial nitrification. Bicarbonate was added into the wastewater only once from the beginning, supplied as a carbon source, and alkalinity was adjusted as necessary for partial nitrification. An optimal initial alkalinity of $1500 \mathrm{mg} \mathrm{CaCO}_{3} l^{-1}$ was necessary for $50 \%$ partial nitrification of wastewater with an initial ammonium concentration of $510 \mathrm{mg} \mathrm{NH}_{4}-\mathrm{N}^{-1}$ during $24 \mathrm{~h}$ of nitrification. Furthermore, there is no need for $\mathrm{pH}$ adjustment by adding a base or an acid throughout the reaction if the initial alkalinity adjusted by the addition of bicarbonate into the wastewater is appropriately controlled.

The ASL from 10.83 to $5.27 \mathrm{~g} \mathrm{NH}_{4}-\mathrm{N} \mathrm{m}^{-2}$ resulted in approximately $50 \%$ partial nitrification within the same period of time whether the initial ammonium loading was 510 or $250 \mathrm{mg} \mathrm{NH}-\mathrm{N} l^{-1}$. Theoretically, the amount of biofilm formed is relative to the length of the tube; therefore, a sys- 
tem with a longer tube has more extensive biofilm formation and can achieve a faster reaction within the same period of time. In other words, around 50\% partial nitrification can be achieved easily by adjusting the tube's length in accordance with the range of initial ammonium loading.

As mentioned above, the MBR system developed in this study is very stable and easy to operate. This system has great flexibility for partial nitrification, making it an ideal pretreatment system for Anammox. The combination of this MBR system with the subsequent Anammox has great potential for the rapid treatment of ammonium-rich wastewater.

\section{ACKNOWLEDGMENTS}

The authors would like to thank the National Science Council of the Republic of China for financially supporting this research under Contract no. NSC 94-2211-E-236-002.

\section{REFERENCES}

1. van Loosdrecht, M. C. M. and Jetten, M. S. M.: Microbiological conversions in nitrogen removal. Water Sci. Technol., 38, 1-7 (1998).

2. Ciudad, G., Rubilar, O., Munoz, P., Ruiz, G., Chamy, R., Vergara, C., and Jeison, D.: Partial nitrification of high ammonia concentration wastewater as a part of a shortcut biological nitrogen removal process. Process Biochem., 40, 17151719 (2005).

3. Ruiz, G., Jeison, D., and Chamy, R.: Nitrification with high nitrite accumulation for the treatment of wastewater with high ammonia concentration. Water Res., 37, 1371-1377 (2003).
4. Khin, T. and Annachhatre, A. P.: Novel microbial nitrogen removal processes. Biotechnol. Adv., 22, 519-532 (2004).

5. Strous, M., Heijnen, J. J., Kuenen, J. G., and Jetten, M. S. M.: The sequencing batch reactor as a powerful tool for the study of slowly growing anaerobic ammonium-oxidizing microorganisms. Appl. Microbiol. Biotechnol., 50, 589-596 (1998).

6. Ferhan, C.: Investigation of partial and full nitrification characteristics of fertilizer wastewaters in a submerged biofilm reactor. Water Sci. Technol., 34, 77-85 (1996).

7. Brindle, K., Stephensen, T., and Semen, M. J.: Nitrification and oxygen utilization in a membrane aeration bioreactor. J. Membr. Sci., 144, 197-209 (1998).

8. Ho, C. M., Tseng, S. K., and Chang, Y. J.: Autotrophic denitrification via a novel membrane-attached biofilm reactor. Lett. Appl. Microbiol., 33, 201-205 (2001).

9. Hsieh, Y. L., Tseng, S. K., and Chang, Y. J.: Nitrification using polyvinyl alcohol-immobilized nitrifying biofilm on an $\mathrm{O}_{2}$-enriching membrane. Biotechnol. Lett., 24, 315-319 (2002).

10. Wang, J. and Ning, Y.: Partial nitrification under limited dissolved oxygen condition. Process Biochem., 39, 1223-1229 (2004).

11. van Dongen, U., Jetten, M.S. M., and van Loosdrecht, M. C. M.: The SHARON-ANAMMOX process for treatment of ammonium rich wastewater. Water Sci. Technol., 44, 153160 (2001).

12. Hanaki, K., Wantawin, C., and Ogaki, S.: Nitrification at low levels dissolved oxygen with and without organic loading in a suspended-growth reactor. Water Res., 24, 297-302 (1990).

13. Jetten, M., Wagner, M., Fuerst, J., van Loosdrecht, M., Kuenen, G., and Strous, M.: Microbiology and application of the anaerobic ammonium oxidation ('ANAMMOX') process. Curr. Opin. Biotechnol., 12, 283-288 (2001). 